\title{
Substance use to enhance occupational performance and experience: a critical interpretive synthesis
}

\author{
Niki Kiepek ${ }^{\mathrm{a}}$ (D), Brenda Beagan ${ }^{\mathrm{a}}$ (D), Shanon Phelan ${ }^{\mathrm{b}}$ \\ ${ }^{a}$ Dalhousie University, Halifax, NS, Canada. \\ ${ }^{b}$ University of Alberta, Edmonton, AB, Canada.
}

\begin{abstract}
Introduction: Substance use, as an occupation, is typically portrayed as problematic and the target of occupational therapy intervention and remediation. At the same time, psychoactive substances may be used to enhance mood, cognition, occupational performance, and/or experience, a perspective that is largely absent from occupation scholarship. Objective: We examine substance use in relation to the enhancement of occupation, drawing on the theoretical notion of agential realism. This theory suggests that in the social world 'reality' is not so much objective fact, stable and predictable, but rather continuously produced and reproduced, through doing and intra-active becoming. Method: A selected integrative, critical interpretive synthesis of the literature was conducted. The analysis is focused on synthesizing literature about substance use and enhancement of occupation. Results: Occupation does not exist independent of the doing, but also in 'becoming'. Sometimes using a substance is in itself an occupation - having a drink, or going out for coffee. Sometimes using a substance is a means to enhance another occupation - taking erectile dysfunction medication to improve sex, or amphetamines to improve studying. Sometimes using a substance simply alters the experience of an occupation - using cannabis or psychedelics to enhance the experience of listening to music. Conclusion: Adopting a focus on occupation may encourage novel ways of understanding substance use and what constitutes optimal quality of life and meaningful experiences. It may also facilitate better understandings of how people employ alternative, non-substance means to achieve desired occupational outcomes.
\end{abstract}

Keywords: Meaningful Use/Drug Effects, Street Drugs, Cognitive Social Capital, Role Playing, Agential Realism.

\section{Uso de substâncias para melhorar o desempenho e a experiência ocupacional: uma síntese interpretiva crítica}

Resumo: Introdução: O uso de substâncias, como uma ocupação, é tipicamente retratado como problemático e alvo de intervenção e remediação da terapia ocupacional. Ao mesmo tempo, substâncias psicoativas podem ser usadas para melhorar o humor, a cognição, o desempenho ocupacional e/ou a experiência, sendo, contudo, uma perspectiva que está muito ausente nos estudos de ocupação. Objetivo: Examinar o uso de substâncias em relação ao aprimoramento da ocupação, com base na noção teórica de realismo agencial. Essa teoria sugere que, no mundo social, a 'realidade' não é um fato objetivo, estável e previsível, mas sim continuamente produzido e reproduzido, através do fazer e do tornar-se intra-ativo. Método: Uma síntese interpretativa crítica integrativa selecionada da literatura, conforme conduzida. A análise está focada na síntese de literatura sobre uso de substâncias e aprimoramento da ocupação. Resultados: A ocupação não existe independentemente do que está sendo feito, mas também do "tornar-se". Às vezes, o uso de uma substância é em si uma ocupação - tomar um drink ou sair para tomar um café. Às vezes, usar uma substância significa um meio de melhorar outra ocupação - tomar medicamentos para disfunção erétil para melhorar o sexo ou anfetaminas para melhorar o estudo. Às vezes, o uso de uma substância altera simplesmente a experiência de uma ocupação - usar cannabis ou psicoativos para melhorar a experiência de ouvir música. Conclusão: A adoção

Corresponding author: Niki Kiepek, Dalhousie University, University Avenue, B3H 4R2, Forrest Building, 5869, Room 211, PO Box 15000, Halifax, NS, Canada, e-mail: niki.kiepek@dal.ca

Received on Apr. 10, 2019; $1^{\text {st }}$ Revision on Aug. 10, 2019; Accepted on Sept. 16, 2019.

This is an Open Access article distributed under the terms of the Creative Commons Attribution License, which permits unrestricted use, distribution, and reproduction in any medium, provided the original work is properly cited. 
de um foco na ocupação pode incentivar novas maneiras de entender o uso de substâncias e o que constitui uma qualidade de vida ideal e experiências significativas. Também pode facilitar uma melhor compreensão de como as pessoas empregam meios alternativos e não substanciais para alcançar os resultados ocupacionais desejados.

Palavras-chave: Uso Significativo/Efeito da Droga, Drogas Ilícitas, Capital Social Cognitivo, Desempenho de Papéis, Realismo Agencial.

\section{Introduction}

Most people who are regular consumers of psychoactive drugs are not drug addicts, nor will they ever become addicts (MÜLLER; SCHUMANN, 2011, p. 293).

Substance use is increasingly addressed in occupational therapy and occupational science as an occupation (KIEPEK; MAGALHÁES, 2011; KIEPEK; PHELAN; MAGALHÃES, 2014; WASMUTH; CRABTREE; SCOTT, 2014; KIEPEK et al., 2018). In this literature, as in most health sciences literature, substance use is typically portrayed as problematic and subject to occupational therapy intervention and remediation (AMORELLI, 2016; ROJO-MOTA; PEDRERO-PÉREZ; HUERTAS-HOYAS, 2017; MCCOMBIE; STIRLING, 2018; NHUNZVI; GALVAAN; PETERS, 2019). In this article, to offer a counter-perspective, substance use will be explored in relation to enhancement of occupation.

Enhancement properties are foundational to pharmaceutical uses of substances, including enhanced physiological functioning (e.g., vasodilator medication to reduce hypertension), enhanced mood (e.g., anti-depressants, anxiolytics), enhanced cognition (e.g., methylphenidate to reduce symptoms of ADHD), and enhanced performance (e.g., erectile dysfunction medications, sleep medications). Certain pharmaceutical substances, licit substances, and illicit substances can be used in ways that are not prescribed in order to achieve a desired enhancement effect. For instance, steroids may be used to enhance performance in sports, ecstasy can enhance the experience of dancing, 3,4-methylenedioxy-methamphetamine (MDMA) can enhance intimacy (SOLOWIJ; HALL; LEE, 1992), illicit "recreational" substances [i.e., cannabis, ecstasy, MDMA, cocaine, crystalline methamphetamine, dimethyltrytamine (DMT), d-lyseric acid diethyamide (LSD)] can enhance social engagement (MEY et al., 2018), and alcohol can enhance feelings of confidence (NEWBURY-BIRCH; WALSHAW; KAMALI, 2001). In our previous research that explores substance use by professionals and students in professional programs, we found the more commonly reported effects of substances were those that directly or indirectly enhanced performance (e.g., sleep, socialisation), mood (e.g., manage stress, relax), cognition (e.g., energy, clarity of thought), and the general experience of activities (e.g., enjoyment) (blinded for review). In this study, we consider enhancement of occupational performance, engagement, and experience. We examine components of occupation that influence these concepts, which is consistent with several models of occupation, such as the Canadian Model of Occupational Performance (e.g., cognitive, affective, physical; TOWNSEND; POLATAJKO, 2007), Model of Human Occupation (e.g., personal causation, interests, skills; KIELHOFNER; BURKE, 1980), and the Occupational Therapy Intervention Process Model (e.g., neurologic, musculoskeletal, cognitive, and psychosocial capacities, motivation; FISHER, 1998).

While enhancement properties of substances are not unfamiliar, they have not been considered specifically in relation to occupation. Certainly, people experience adverse effects and undesired consequences associated with use and, while desired/undesired, beneficial/harmful effects tend to coexist, existing substance use literature tends to focus on problematic effects and risk. For the purpose of this paper, we focus on enhancement. We aim to explore this relationship using Karen Barad's (2003, p. 822, italics in original text) notion of agential realism. According to this perspective,

[...] matter does not refer to a fixed substance; rather, matter is substance in its intra-active becoming - not a thing, but a doing, a congealing of agency. Matter is a stabilizing and destabilizing process of iterative intra-activity. Phenomena-the smallest material units (relational "atoms")—come to matter through this process of ongoing intra-activity. That is, matter refers to the materiality/materialization of phenomena, not to an inherent fixed property of abstract independently existing objects of Newtonian physics.

The term intra-action ontologically problematises discrete boundaries of materiality, drawing on Niels Bohr's proposition that objects do not have inherently determinant boundaries or properties (BARAD, 2003). This idea of agential realism suspends assumptions that there exist fixed properties that 
act in predictable stable ways. Accordingly, agential realism suggests that,

[...] each encounter reproduces reality uniquely, based on the specifics of people, objects and concepts encountering each other and being remade in these encounters (FRASER; MOORE, 2011b, p. 5).

According to agential realism, it is possible to consider the active or agential aspect of materialism, noting that,

Intra-actions always entail particular exclusions, and exclusions foreclose any possibility of determinism, providing the condition of an open future. Therefore, intra-actions are constraining but not determining (FRASER; MOORE, 2011b, p. 826).

To relate this to substances, experiences of substance use will be constrained by the parameters of the substance in intra-action with the person within a certain context, but with unique variability. For instance, the phenomenon of a person receiving an opioid by injection, and the impact on occupation, would vary by whether the person was receiving this in a hospital for an acute medical reason, during palliative care treatment, for experimental use, or to avoid withdrawal after long-term use, even if it was the same dose of the same substance using the same type of syringe. In fact, research shows that a person who has developed a tolerance to a substance can overdose when using their typical dose in an unfamiliar setting (GEREVICH et al., 2005).

Drawing on agential realism, occupation can be understood not as something that occurs from a person engaging in a particular manner, with particular materials, in particular contexts, but a "becoming". This is not becoming in the sense of identity or meaning, which tends to be espoused in occupational therapy literature, but the becoming of the phenomenon within that time and space. Explained by Barad (2003, p. 818),

[...] the universe is agential intra-activity in its becoming. The primary ontological units are not 'things' but phenomena - dynamic topological reconfigurations/entanglements/ relationships/(re)articulations.

Bringing this to the study of occupation, efforts to define, categorise, measure, and generalise occupation are problematised, encouraging reconceptualizations at an ontological level, questioning what it means to be, become, and exist.
Agential realism is a theory used by substance use scholars to inform new understandings about lived experiences (MOORE, 2004; FRASER; VALENTINE, 2008; RACE, 2009; FRASER; MOORE, 2011a; DUFF, 2013; KEANE, 2013; POULSEN, 2015). We build on this work by deliberately focussing on occupation as a factor of analysis. Agential realism provides a theoretical framework from which to reinforce the notion that occupations are neither static nor universal. In this article, we examine ways in which substances can alter and shape performance of occupation, engagement in occupation, and experience of occupation.

\section{Methods}

A selected literature review was conducted, combining integrative (DIXON-WOODS et al., 2005; WHITTEMORE; KNAFL, 2005; ANTHONY; JACK, 2009; AGARWAL et al., 2015) and critical interpretive (DIXON-WOODS et al., 2005) approaches. The integrative analysis is focussed on synthesizing literature about substance use and enhancement of occupation. Literature reviewed was published in English, with no limits on date. Databases searched include CINAHL, Medline, Social Sciences Citation Index, PsycInfo, and EMBASE. This is not an exhaustive review of all articles that address substance effects and enhancement impacts on occupation; rather, exemplar articles were selected. A deliberate search enhanced feasibility, as the literature, and associated keywords, tend toward dominant representations of substance use as inherently problematic and risky. For instance, using the search term "confidence" to indicate a desired substance use effect is more likely to result in articles related to addictions concepts related to one's confidence to refrain from use; the term "socialisation" typically generates literature about social factors that influence initiation of substance use, rather than a strengthened social bond experienced when engaging in substance use collectively. Keywords used to guide data collection included: performance enhancement drugs; cognitive enhancement; mood enhancement. Occupations were then identified within these articles. There terms "drugs" and "substances" were used, as well as individual names (i.e., alcohol; MDMA; benzodiazapines) were combined with specific occupations (i.e., sleep, sports, productivity) and occupation related components that impact engagement, performance, and experience (e.g., pain, energy).

The literature review focussed on theoretical and empirical research articles pertaining to enhancement effects experienced through use of substances that had a direct or indirect effect on occupation. 
Enhancement effects were organised according to i) mood; ii) cognition; iii) performance; iv) quality of experience. It is important to note that although these categories were used to organize the findings, they are not discrete and there is unavoidable overlap. The interpretive analysis examines the impact of substance use on occupation and how these experiences are made sense of by the person, in relation to agential realism, considering constrained variability of reported experiences. Music lyrics embedded throughout highlight the ubiquitousness of these themes in public discourses.

\section{Results}

\subsection{Mood enhancement}

I smell dope, I smell dope, I smell dope, I am smelling dope

\section{Holiday}

We're so good, Wére so good, We're so good, man we've never been so good

Wére so nice, Wére so nice, Wére so nice, man wève never been so nice (HAPPY MONDAYS, 1990).

Several pharmaceutical substances are targeted at mood enhancement, with anti-depressants and anxiolytics (anti-anxiety medication) among the most common. In the United States, in 2013, 12\% of adults reported filling a prescription for anti-depressants and $8.3 \%$ for anxiolytics, sedatives, and hypnotics combined (MOORE; MATTISON, 2017). These are more typically used by women than men and by Caucasians (compared to Hispanic, Black, and Asian adults), with prevalence increasing with age (MOORE; MATTISON, 2017).

Other licit and illicit substances are reported to have mood enhancement effects. Relaxation is a key reason for using marijuana (GREEN; KAVANAGH; YOUNG, 2004), along with reducing stress and forgetting problems (LORENTE; PERETTI-WATEL; GRELOT, 2005; LEE; NEIGHBORS; WOODS, 2007). Tobacco is reported to elicit feelings of fun, pleasure, excitement and enjoyment, and to aid in relaxation, reduced frustration, and release of tension (NEWBURY-BIRCH; WHITE; KAMALI, 2000; MCKENNA et al., 2001; BUDHATHOKI et al., 2010; PIASECKI et al., 2011). Alcohol is reported by students to relieve the frustration of studying (BUDHATHOKI et al., 2010). It also improves mood, reduces feelings of stress, anxiety, and tension, and relieves work and school pressures (NEWBURY-BIRCH; WALSHAW; KAMALI,
2001; YANG; YANG; PAN, 2001; SMITH, 2013). The first drink in an "episode" is reported to elicit enthusiasm, excitement, and happiness, while decreasing feelings of distress and sadness (PIASECKI et al., 2011).

Substance-related mood changes may also affect performance. A positive mood is associated with improved competitive sport performance (TRIVIÑO, 2014). For example, in sport dextroamphetamine, which reduces impulsivity, has been shown to have desirable performance effects in baseball and cricket (TRIVINO, 2014).

\subsection{Cognitive enhancement}

\section{I'm churning out novels like}

\section{Beat poetry on Amphetamines (DEL REY, 2014).}

Research indicates heightened use of cognitive enhancement substances such as methylphenidate (e.g., Ritalin), amphetamines (e.g., Adderall, Dexadrine), and modafinil, by students, military personnel, and ageing individuals (REINER; GRUZELIER; BAMIDIS, 2017). Among university students, past-year prevalence of non-prescribed use of cognitive enhancement substances is as high as 20\% (WHITE; BECKER-BLEASE; GRACE-BISHOP, 2006; RACINE; FORLINI, 2010; DIETZ et al., 2013; WEBB; VALASEK; NORTH, 2013). One study found that more than $90 \%$ of cognitive enhancement substance use was non-prescribed (WHITE; BECKER-BLEASE; GRACE-BISHOP, 2006). Among a sample of surgeons, $15-20 \%$ used illicit or prescribed substances exclusively for enhancement of cognition or mood (FRANKE et al., 2013) and another study found that $20 \%$ of a sample of academics used cognitive enhancers (methylphenidate, modafinil, beta-blockers) for non-medical reasons (MAHER, 2008).

Reported effects or incentives for use include enhanced performance in demanding jobs, amelioration of age-related cognitive decline, increased wakefulness and alertness, and improved focus, concentration, attention, working memory, and self-control (HUGHES et al., 1991; PETROIANU et al., 2010; HABIBZADEH et al., 2011; EMANUEL et al., 2013; ENCK, 2013; REINER; GRUZELIER; BAMIDIS, 2017). Desired cognitive outcomes include enhanced capacity for learning, improved studying and academic performance, and increased competitiveness for work or school positions (HUGHES et al., 1991; EMANUEL et al., 2013; REINER; GRUZELIER; BAMIDIS, 2017). 
One person described Ritalin as a study tool, "[...] just like a tutor and caffeine pills" (KHAN, 2003 apud RACINE; FORLINI, 2010, p. 3). Students also report cognitive enhancement substances can make their work seem more interesting (DESANTIS; WEBB; NOAR, 2008). There is some indication that cognitive enhancement medications are sought by parents for use by their children, as a means to improve capacity in an increasingly competitive culture of the education system (COLANERI; SHELDON; ADESMAN, 2018).

Interestingly, a high quality systematic review suggests that actual effects are generally lower than perceived effects (REPANTIS et al., 2010). Another review shows there is no conclusive evidence that substances typically referred to as cognitive enhancers improve cognitive capacitive among healthy, non-sleep deprived individuals, though affect and motivation may be altered (ZOHNY, 2015). Based on a qualitative study with university students, Vrecko (2013) suggests that the perceived efficacy of these substances is based on emotional or affective effects that increase "feeling up," "drive", "interest" in and "enjoyment" of performing otherwise less engaging tasks.

Contextual factors influence the use of substances intended to enhance cognition. Research indicates that children in higher socioeconomic classes are more likely to use cognitive enhancement substances, as are those who live in districts that have stricter educational accountability (COLANERI; SHELDON; ADESMAN, 2018). Work pressures, private life pressures, and gross income are positively correlated with the use of substances for cognitive and mood enhancement (FRANKE et al., 2013).

Other substances reported to have cognitive enhancement effects - though perhaps not intended - include caffeine, alcohol, nicotine, cannabis, and cocaine. Caffeine is reported to enhance performance of work, school, and driving and may support social engagement (YANG; YANG; PAN, 2001; LEE et al., 2009). Low levels of alcohol can facilitate creative problem solving (BENEDEK et al., 2017). Nicotine has been shown to improve attention, memory, and mental processing (NEWHOUSE et al., 2012) as well as executive functioning and prospective memory (JANSARI et al., 2013). Such cognitive effects compared to placebo appear not to be the result of expectations (HARRELL; JULIANO, 2012). Cocaine enhances prospective memory (HUTTEN et al., 2018). While cannabis is more often used for relaxation and social effects, a significant number of people report using it for cognitive enhancement (GREEN; KAVANAGH; YOUNG,
2004). A German survey of 1538 university students suggested cannabis users reported higher perceptions of pressure to perform (FRANKE et al., 2016). While not used nearly as much as amphetamines for studying and exam performance, cannabis was still widely used, particularly to deal with "general professional stress". The authors conclude cannabis

[...] may be perceived as contributing to $\mathrm{CE}$ [cognitive enhancement] in a wider sense, for example, by furthering the period of relaxation between cognitively demanding situations (FRANKE et al., 2016, p. 1860).

\subsection{Occupation-based performance enhancement}

Mother needs something today to calm her down And though she's not really ill There's a little yellow pill She goes running for the shelter of a mother's little helper And it helps her on her way, gets her through her busy day (JAGGER; RICHARDS, 1966).

Enhancement drugs are described as having the potential to i) compensate for disease- or illness-related dysfunction; ii) facilitate performance beyond a persons' typical capabilities; or iii) strive for performance beyond what is considered humanly possible (FORLINI, 2018). Antihistamines are a type of substance that alleviate physiological symptoms associated with allergies, thereby improving mood and reducing fatigue, which can enhance performance, sleep, and quality of life (DAVIS, 2015). Caffeine may enhance performance beyond typical capabilities by increasing alertness and wakefulness beyond natural limits. Research indicates that caffeine can directly improve psychomotor performance and vigilance (TEMPLE et al., 2018). Striving beyond what is considered humanly possible aligns with ideas of transhumanism. Transhumanism is a movement toward "[...] radical enhancement of human performance via technoscientific and biomedical advances", which may be facilitated through substances (LE DÉVÉDEC, 2018, p. 488). For instance, one might imagine a substance that slows the aging process and enables higher levels of performance throughout the lifespan. In this section, we focus on the first two ways in which substances impact performance.

Performance enhancement can be difficult to categorise as distinct from mood and cognitive enhancement, as substances may enhance performance indirectly. For instance, amphetamines are used to enhance studying for exams by altering cognition (FRANKE et al., 2016). Substances that are more 
directly associated with performance are sedatives for sleep, erectile dysfunction medications, and sexual enhancement drugs (MUSACCHIO; HARTRICH; GAROFALO, 2006).

Many people seek substances to improve sleep. Benzodiazepines are the substance most commonly prescribed to improve sleep; however, actual effectiveness among older adults has recently been challenged (BÉLAND et al., 2010). Prescribed and over-the-counter substances, such as sedative-hypnotics, dimenhydrinate (e.g., Gravol) and diphenhydramine (i.e., Benadryl) are frequently used as sleep aids (SPROULE et al., 1999; LANDE; GRAGNANI, 2010), and melatonin is a hormone increasing supplement supported in research to aid in sleep (APPLETON; GRINGRAS, 2013). Cannabis, which in some contexts can be prescribed, purchased legally and/or illegally, is reported to enhance sleep (LORENTE; PERETTI-WATEL; GRELOT, 2005).

Substances are used to enhance productive occupations. Modafinil and armodafinil are reported to enhance driving among shift workers with sleep disorders (SCHWARTZ; ROTH, 2006). Cocaine has reportedly been used to enhance driving following a weekend of heavy substance use and lack of sleep, though study participants recognised their driving performance is better when sober (ZDUN, 2014). Tranquilizers are reported to help one remain and appear calm during stressful work situations (MORISSETTE; DEDOBBELEER, 1997). Similarly, as noted in the Rolling Stones lyrics above, Valium and other calming drugs were widely prescribed in the 1960s to help housewives and mothers maintain even affect under stress.

Substances may also be used for performance enhancement in sport. Hoberman (1992 apud TRIVIÑO, 2014, p. 26) noted the challenge in distinguishing between physical and mental effort in sport, defining sport performance as "[...] any mental or physical effort that is subjected to psychological or physiological measurement or assessment". This indicates that sport enhancing substances may include those that enhance physiological performance, cognition, and/or mood. Sport enhancement substances include anabolic androgenic steroids (AAS), hormones, beta-2 agonists, anti-estrogens, stimulants, narcotics, cannabinoids, glucocorticosteroids, alcohol, beta blockers, and erythropoietin (EPO) (TRIVIÑO, 2014). Caffeine is also associated with enhanced sport performance (STADHEIM et al., 2013), with effects that include faster reaction time, increased alertness, and improved mood (DODD et al., 2015). E-athletes, who compete in virtual space, have reportedly been targeted for substance use screening, as it is thought that cognitive enhancers might improve competitive performance (DANCE, 2016).

Social and/or intimate relationships may be enhanced by the use of licit and illicit substances, such as cannabis, opioids, stimulants (e.g., amphetamines), and alcohol (LEE; NEIGHBORS; WOODS, 2007; IP; HEUBECK, 2016; DE WIT; SAYETTE, 2018) and pharmaceuticals, such as anti-depressants (YOUNG; MOSKOWITZ; AAN HET ROT, 2014). Enhanced social experiences and increased enjoyment at parties attributed to cannabis may be related to associated relaxation effects (LORENTE; PERETTI-WATEL; GRELOT, 2005). Use of MDMA is associated with amicability and gregariousness (DUMONT et al., 2009) and is reported to enhance social interactions (WARDLE; DE WIT, 2014). It increases positive word use, perception of positive empathy in others, and heightens responses to happy expression, while slowing the perception of angry expressions (HYSEK; DOMES; LIECHTI, 2012; WARDLE; DE WIT, 2014). Other effects include enhanced mood and well-being, happiness, relaxation, emotional sensitivity and responsiveness, openness, extroversion, and a feeling of closeness to other people (THAL; LOMMEN, 2018). Once used to enhance psychotherapy, it is currently most commonly used in the West recreationally, either on its own or as an ingredient in ecstasy, for nightclubs and all-night dance parties (NATIONAL..., 2015). Finally, LSD is perceived to increase emotional empathy (except in relation to fear) (DOLDER et al., 2016), which may engage social connectedness and social occupations.

Erectile dysfunction medications are intended to promote the ability to achieve an erection and engage in penetrative sex and intimacy. Use has moved beyond those diagnosed with erectile dysfunction to those experiencing natural age-related changes. Among some young people, these substances are used in combination with alcohol, amphetamines, and/or ecstasy, to heighten sex drive and reduce inhibitions (MUSACCHIO et al., 2006). Research pertaining to men who have sex with men found that erectile dysfunction medications were more likely to be associated with insertive sex roles, 'poppers' with receptive roles, and crystal methamphetamine for all roles (RICH et al., 2016).

Throughout history, psychedelic substances have been used in rituals and ceremonies and have been integrated into religious and spiritual practices (MÓRÓ; NOREIKA, 2011). It is suggested that psychedelics can elicit an experience of transcendence, a mystical experience imbued with meaning and significance (MÓRÓ; NOREIKA, 2011). Psychoactive plants 
used as spiritual sacrament have been referred to as "plant teachers" (TUPPER, 2002). Tupper (2002, p. 503) proposes that these substances can facilitate "existential intelligence", described as

[...] a heightened capacity to appreciate and attend to the cosmological enigmas that define the human condition, an exceptional awareness of the metaphysical, ontological, and epistemological mysteries.

In these ways, substances may enhance engagement in and experience of occupations with sacred meaning.

\subsection{Quality of experience}

My life was empty, forever on a down

Until you took me, showed me around

My life is free now, my life is clear

I love you, sweet leaf, though you can't hear (OSBOURNE et al., 1971).

Again, distinguishing enhancement of cognition, mood and performance from enhancement of the quality of an experience is not straightforward. But, given the considerable overlap, some substances are clearly used to enhance experiences.

On one hand, substances may be used to directly affect the "doing" of occupation, and how one experiences that occupation. For example, Cannabis is reported to enhance perception or perspectives (e.g., increase enjoyment of activities) and enhance experiences (e.g., daily activities are more interesting, enhance sounds of music) (LEE; NEIGHBORS; WOODS, 2007). It also decreases boredom by providing something to do (LEE; NEIGHBORS; WOODS, 2007), as suggested in the Black Sabbath lyrics above. Narcotics and analgesics are often used to reduce pain (YANG; YANG; PAN, 2001) and efficacy may be measured in relation to enhanced performance of daily activities (e.g., CALANDRE et al., 2011) as well as quality of experience. Similarly, pharmaceutical treatment of fatigue related to certain diagnoses may enhance engagement and performance of daily activities (MÜCKE et al., 2015).

Substances may also be used to enhance a sense of self and well-being. Nour and Carhart-Harris (2017) explain the potential therapeutic effect of psychedelics and the impact on "self." Psilocybin (magic mushrooms), for instance, is correlated with positive well-being, increased openness, and meaningfulness/spiritual significance of an experience. Evidence of ego-dissolution, experienced as a "[...] loss of boundaries between the subject and the objective world, with ensuing feelings of unity" and improved well-being are associated with use of psychedelics (GROF, 1980 apud NOUR; CARHART-HARRIS, 2017). Cocaine, on the other hand, is associated with ego-inflation, an experience of "self-centredness" (NOUR; CARHART-HARRIS, 2017), and potential increased self-confidence (ALDRIDGE; MEASHAM; WILLIAMS, 2011). LSD was once used as an adjunct to psychotherapy and was widely used to enhance creativity and connection in the 1960s counterculture in North America. Research has indicated a positive lasting impact on personal values, attitudes, and personality (SCHMID; LIECHTI, 2018). Other persisting effects, 1-year after a single, clinically monitored dose, include positive attitudes about life and/or self, positive mood changes, altruistic/positive social effects, and positive behavioral changes (SCHMID; LIECHTI, 2018). Participants reported use of LSD as a personally and spiritually meaningful event, with increased ratings of well-being or life satisfaction (SCHMID; LIECHTI, 2018).

\section{Discussion}

I can feel the endorphins

kicking in kicking in kicking in

you take the minuses

and leave me with the plusses

oh, my sweet serotonin rushes!

Wait! I'm still thinking

I can feel us disintegrating

I think we are gradually becoming a part of the seams

I think deep down

you probably agree (FUJIYA; MIYAGI, 2017).

The focus taken in this paper is to convey potential occupation-related enhancement experiences associated with substance use. For a more comprehensive synthesis of all possible enhancement experiences related to substance use, beyond occupation, refer to Muller and Schumann (2011). Our search strategy did not yield literature from occupational therapy or occupational science; however, enhancement effects 
from substances are reported by some scholars. For instance, Kiepek and Magalhães (2011) and Kiepek et al. (2018) cite a number of examples of enhancement effects in relation to the concept of occupation. Wasmuth, Brandon-Friedman and Olesek (2016) found through interviews that substance use contributed to social connections, interpersonal bonding, enjoyment, structure, and one's sense of identity. During interviews about the occupational transition from smoking to not smoking, Luck and Beagan (2015) discovered benefits from smoking were stronger relationships and connections, less preoccupation, a sense of regaining time, and feelings of personal accomplishment. A literature review by Gish, Kiepek and Beagan (2019) uncovered ways in which using methamphetamines can alter engagement in and performance of occupations, such as sex, socializing, productivity (e.g., work, household chores), and leisure (e.g., dancing, playing pool). Helbig and McKay (2003) cited the potential for substance use to contribute to a personal sense of identity and meaningfulness.

As noted previously, the search strategy was purposefully designed to select articles that provide a counter-narrative to dominant analyses that foreground actual and potential harms and negative impact on occupation, thereby providing a partial representation of substance use. As reported in the findings, not all reported effects are substantiated by empirical research - even those for which substances are prescribed. It is not our intent to advocate for substance use, but to contribute to nuanced understandings of varied experiences in relation to substance use and occupation. We conclude with discussions about the complexities of substance use in relation to occupation, opportunities afforded by applying agential realism as a theoretical approach, and how the findings are situated in relation to concepts of non-sanctioned occupations.

\subsection{Complexities of substance use in relation to occupation}

In occupational therapy, use of pharmaceuticals tends to be accepted and occupational therapists may set goals related to medication management. This study reveals the challenge of distinguishing between therapeutic use of a substance and enhancement (COLANERI; SHELDON; ADESMAN, 2018). Therapeutic use that is monitored by regulated health professionals tends to be considered more valid and (socially) acceptable, with a focus on remediating a deficit. These deficits tend to be viewed according to a measurable set of criteria established quantitatively through population norms. Enhancement use is less socially sanctioned (though not necessarily less common) and may be viewed as "cheating" or violating "rules of fair competition" (ENCK, 2013, p. 155). These types of distinctions regarding whether substance is used as treatment or enhancement, and related questions pertaining to equality, fairness, authenticity, and autonomy, are considered a reflection on "the nature of being human" and what are idealised ways of doing and being (BULLARD, 2018). For instance, Müller and Schumann (2011, p. 293) propose that use of psychoactive substances with an intent to alter other non-drug-related behaviours (occupations) can be viewed as "functional adaptation to modern environments", such as highly demanding workloads. From this perspective, substance use is highly related to contextual demands in which expectations for occupational performance are situated.

As noted above, perceptions of enhanced performance may be due less to direct effects of psychoactive properties, and more to indirect effects such as increased interest in the occupation and improved mood (VRECKO, 2013). This is an underrepresented consideration in substance-related research and of importance to occupation. Typically, research about substance use effects or reasons for use neglect to take into account occupation-related outcomes or expectations. For instance, improving mood, decreasing pain, and reducing fatigue can be considered desirable end goals in themselves. However, they are also components that impact occupational performance and occupational engagement. Therefore, it may be worth examining occupation-related implications of achieving these states. Decreased pain may be desirable to allow one to engage in a sport (PARTRIDGE, 2013) or engage in paid work, which might otherwise be impossible or uncomfortable when experiencing a certain threshold of pain. Similarly, improved mood may allow a person to more fully engage in social or work activities.

Adopting a focus on occupation may encourage novel ways of understanding substance use and what constitutes optimal quality of life and meaningful experiences. It might be worth exploring alternative means to achieve desired outcomes without necessarily using substances, as represented in the lyrics of Ms. Dynamite's Natural High (DYNAMITE, 2002):

Fuck powder, fuck pills, see me Strictly chemical-free like sweet sensi Fuck coke, fuck ecstasy My music get me high as I need. 
At the same time, a focus on substances in relation to occupational outcomes and desires blurs the lines between sanctioned and non-sanctioned use of substances for enhancement. Whether caffeine or cocaine for mental clarity, whether cannabis or benzodiazepines for sleep - the sought-after occupational effects are the same. Understanding the occupational implications of substance use may alter the focus of occupational therapy interactions with clients who use substances to enhance some aspects of occupation.

\subsection{Incorporating agential realism as a theoretical approach}

Returning to agential realism, analysis becomes less linear regarding the relationship between consuming a substance and the impact on occupation. Many factors complicate the relationship. For instance, perceptions of medication efficacy depend on brand names, colour, and number of tablets, indicating that effects are not solely dependent on pharmacological properties (MOERMAN, 2002). Actual and perceived substance effects are affected by the form of the substance, the route of administration, rituals or patterns of use, the physical context, social context, activities and demands preceding use and following use, expectancy, even how tired a person is or whether they have eaten during the day.

Substance use can both transform occupation and transform the experience of engaging in an occupation. For the sake of this discussion the intra-action of interest is person-substance-occupation. In this case, "substance" refers to the psychoactive effects of the substance. Substance use may be an occupation that is being engaged in simultaneously with another occupation, in which case the intra-action is person-substance-occupation-occupation. Given that people may use more than one substance concurrently, the intra-actions can become even more complex. With respect to the social sanctioning of occupations, this type of intra-action brings up intriguing ethical perspectives. For instance, Enck (2013, p. 163) argues the use of cognitive enhancement substances as a means to achieve "human excellence" can be viewed as a virtuous endeavour. Sy et al. (2019) propose that illicit substance can be interpreted, from an occupational justice perspective in the context of the Philippine War on Drugs, as conforming to Filipino social norms, values, and moral standards, as substances can be used to enhance productivity and economic participation.

Taking one step back, with respect to person-occupation-occupation intra-action, examination of occupation has tended to view a single, discrete occupation to occur within temporal and spatial boundaries. Simultaneous engagement in multiple occupations and the transformative nature of this has been neglected. This paper has examined how substance use may transform occupation; however, it is not possible to fully separate psychoactive effects of substances from substance use as an occupation. Nevertheless, the implications for future studies on simultaneous engagement in occupation and how this transforms the occupation are evident. By excluding examination of multiple occupations being engaged in simultaneously, we create artificial and limited understandings of the complexity of human life. How does listening to music while walking to work transform the experience of community mobilisation? How does watching television while preparing a meal transform the occupations? How might providing caregiving while working from home transform both occupations? Or, in this case, how might substance use as an occupation interact with other occupations? By examining occupations as discrete activities in a particular setting at a particular time, unrelated to any other occupation and with minimal attention to the impact of others (other than notions of the social environment and co-occupation), a type of artificial "lab" unrepresentative of lived experience is created. Therapists work with people who engage in occupations in complex real-life contexts.

In this analysis, the effect of substances is an additional factor for consideration. The results indicate that occupations may be transformed through use of substances. For instance, Carnes, Murray and Charpentier (2005) examine ways in which sex and substance use can interact. Though they examine addiction, there is relevance to this discussion. For instance, they describe purposeful hyperventilation from tobacco smoke while engaging in masturbation as providing a "unique high". In some cases, this experience is so desirable that some people refrain from either smoking cigarettes or masturbating without the presence of the other. Substance use can also cause a disinhibiting effect that alters the experience of sex.

Ter Bogt et al. (2002) use the term "dancecstacy" to convey the transformed experience of dance with ecstasy use. They describe "house" style club dancing as a collective experience where the dance style is free and expressive, accompanied by a lot of eye contact, easy smiles, and conversations over loud music. To describe the experience they state,

Never before were dancers so euphoric, never before did they feel so comfortable in their 
own bodies or had conversations been so intense. The music is a cascade of sounds, dancers move in rainbows of colors, and their bodies are rhythm. Self-awareness fades away and time no longer exists. Synchronic dancing with others has the intensity of lovemaking (TER BOGT et al., 2002, p. 172).

A question arises regarding the long-term consequences of certain person-occupation-substance intra-actions. For instance, if a person finds the intra-action with dance and ecstasy to heighten the experience of dancing, will dancing without ecstasy also be transformed to become less desirable than it was prior to using ecstasy? Similarly, if a person tends to engage socially while engaging in occupations of consuming caffeine or alcohol, how would the experience of socialising be transformed without those substances? How would the absence of a psychoactive substance alter the occupation and meaning?

\subsection{Concepts of non-sanctioned occupations}

As detailed above, some substances are intended to alter mood, enhance cognitive performance, improve performance, and may be prescribed for those effects. Other substances - legal or illegal, prescribed or not - are used for similar improvements in occupational experience or performance, in ways that are intentional and deliberate. Viewing some substance use as legitimate and a valued occupation (e.g., going out for "a cup" of coffee) and other substance use as deviant and harmful (e.g., using cocaine to connect and enjoy a social gathering) perpetuates an artificial distinction. Such good-bad substance use categories are grounded in perceptions of safety and harm that have less to do with objective fact than with social constructions. By recognising nuanced experiences of occupations that include sanctioned and non-sanctioned occupations, desired and undesired effects, health inducing and health detracting outcomes (KIEPEK et al., 2018; KIEPEK; PHELAN; MAGALHÁES, 2014), we are better situated to embrace opportunities to ask knew types of questions and develop richer understandings of human engagement in occupation. For therapists, attending to the occupational implications, meanings, and outcomes may be far more helpful than attending to presumed potential for addiction. Attending to enhancement effects - and perhaps impairment effects - is one way to move in this direction.

\section{References}

AGARWAL, S. et al. Evidence on feasibility and effective use of mHealth strategies by frontline health workers in developing countries: systematic review. Tropical Medicine and International Health, Oxford, v. 20, n. 8, p. 10031014, 2015. http://dx.doi.org/10.1111/tmi.12525. PMid:25881735.

ALDRIDGE, J.; MEASHAM, F.; WILLIAMS, L. Illegal leisure revisited. New York: Routledge, 2011.

AMORELLI, C. R. Psychosocial occupational therapy interventions for substance-use disorders: a narrative review. Occupational Therapy in Mental Health, New York, v. 32, n. 2, p. 167-184, 2016. http://dx.doi.org/10.1080/0164 212X.2015.1134293.

ANTHONY, S.; JACK, S. Qualitative case study methodology in nursing research: an integrative review. Journal of Advanced Nursing, Oxford, v. 65, n. 6, p. 1171-1181, 2009. http://dx.doi.org/10.1111/j.13652648.2009.04998.x. PMid:19374670.

APPLETON, R. E.; GRINGRAS, P. Melatonin: helping to MEND impaired sleep. Archives of Disease in Childhood, London, v. 98, n. 3, p. 216-217, 2013. http://dx.doi. org/10.1136/archdischild-2012-303606. PMid:23413423.

BARAD, K. Posthumanist performativity: toward an understanding of how matter comes to matter. Signs, Chicago, v. 28, n. 3, p. 801-831, 2003. http://dx.doi. org/10.1086/345321.

BÉLAND, S. G. et al. Benzodiazepine use and quality of sleep in the community-dwelling elderly population. Aging \& Mental Health, Abingdon, v. 14, n. 7, p. 843-850, 2010. http://dx.doi.org/10.1080/13607861003781833. PMid:20658372.

BENEDEK, M. et al. Creativity on tap? Effects of alcohol intoxication on creative cognition. Consciousness and Cognition, Tallinn, v. 56, p. 128-134, 2017. http://dx.doi. org/10.1016/j.concog.2017.06.020. PMid:28705663.

BUDHATHOKI, N. et al. Substance use among third year medical students of Nepal. Journal of Nepal Health Research Council, Kathmandu, v. 8, n. 1, p. 15-18, 2010. PMid:21879007.

BULLARD, A. Neither licit nor illicit: a discursive analysis of cognition enhancers. Contemporary Drug Problems, Australia, v. 45, n. 3, p. 262-282, 2018. http://dx.doi. org/10.1177/0091450918789415.

CALANDRE, E. et al. Trazodone plus pregabalin combination in the treatment of fibromyalgia: a two-phase, 24-week, open-label uncontrolled study. BMC Musculoskeletal Disorders, London, v. 12, n. 1, p. 1-9, 2011. http://dx.doi. org/10.1186/1471-2474-12-95. PMid:21575194.

CARNES, P. J.; MURRAY, R. E.; CHARPENTIER, L. Bargains with chaos: sex addicts and addiction interaction disorder. Sexual Addiction \& Compulsivity, Evanston, v. 12, n. 2, p. 79-120, 2005. http://dx.doi. org/10.1080/10720160500201371. 
COLANERI, N.; SHELDON, M.; ADESMAN, A. Pharmacological cognitive enhancement in pediatrics. Current Opinion in Pediatrics, Philadelphia, v. 30, n. 3, p. 430-437, 2018. http://dx.doi.org/10.1097/ MOP.0000000000000615. PMid:29538047.

DANCE, A. Smart drugs: a dose of intelligence. Nature, London, v. 531, n. 7592, p. S2-S3, 2016. http://dx.doi. org/10.1038/531S2a. PMid:26934523.

DAVIS, S. Long-term antihistamine use: making the right choice for your patient. South African Pharmacist's Assistant, Arcadia, v. 15, n. 3, p. 275-312, 2015.

DE WIT, H.; SAYETTE, M. Considering the context: social factors in responses to drugs in humans. Psychopharmacology, Berlin, v. 235, n. 4, p. 935-945, 2018. http://dx.doi. org/10.1007/s00213-018-4854-3. PMid:29470605.

DEL REY, L. Brooklyn baby. In: DEL REY, L. Ultraviolence. Califórnia: Interscope, 2014.

DESANTIS, A. D.; WEBB, E. M.; NOAR, S. M. Illicit use of prescription $\mathrm{ADHD}$ medications on a college campus: a multimethodological approach. Journal of American College Health, Washington, v. 57, n. 3, p. 315-324, 2008. http://dx.doi.org/10.3200/JACH.57.3.315-324. PMid:18980888.

DIETZ, P. et al. Randomized response estimates for the 12 month prevalence of cognitive enhancing drug use in university students. Pharmacotherapy: The Journal of Human Pharmacology and Drug Therapy, Carlisle, v. 33, n. 1, p. 44-50, 2013. http://dx.doi.org/10.1002/ phar.1166. PMid:23307544.

DIXON-WOODS, M. et al. Synthesising qualitative and quantitative evidence: a review of possible methods. Journal of Health Services Research \& Policy, Edinburgh, v. 10, n. 1, p. 45-53, 2005. http://dx.doi. org/10.1177/135581960501000110. PMid:15667704.

DODD, F. et al. A double-blind, placebo-controlled study evaluating the effects of caffeine and L-theanine both alone and in combination on cerebral blood flow, cognition and mood. Psychopharmacology, Berlin, v. 232, n. 14, p. 2563-2576, 2015. http://dx.doi.org/10.1007/ s00213-015-3895-0. PMid:25761837.

DOLDER, P. C. et al. LSD acutely impairs fear recognition and enhances emotional empathy and sociality. Neuropsychopharmacology, New York, v. 41, n. 11, p. 26382646, 2016. http://dx.doi.org/10.1038/npp.2016.82. PMid:27249781.

DUFF, C. The social life of drugs. The International Journal on Drug Policy, Amsterdam, v. 24, n. 3, p. 167-172, 2013. http://dx.doi.org/10.1016/j.drugpo.2012.12.009. PMid:23352332.

DUMONT, G. J. H. et al. Increased oxytocin concentrations and prosocial feelings in humans after ecstasy (3,4-methylenedioxymethamphetamine) administration. Social Neuroscience, Hove, v. 4, n. 4, p. 359-366, 2009. http://dx.doi.org/10.1080/17470910802649470. PMid:19562632.
DYNAMITE. Natural high. In: DYNAMITE. A little deeper. United Kingdon: Polydor, 2002.

EMANUEL, R. et al. Cognitive enhancement drug use among future physicians: findings from a multiinstitutional census of medical students. Journal of General Internal Medicine, Philadelphia, v. 28, n. 8, p. 1028-1034, 2013. http://dx.doi.org/10.1007/s11606-012-2249-4. PMid:23595918.

ENCK, G. G. Ideals of student excellence and enhancement. Neuroethics, Oxford, v. 6, n. 1, p. 155-164, 2013. http:// dx.doi.org/10.1007/s12152-012-9164-6.

FISHER, A. G. Uniting practice and theory in an occupational framework. The American Journal of Occupational Therapy, Rockville, v. 52, n. 7, p. 509-521, 1998. http://dx.doi. org/10.5014/ajot.52.7.509. PMid:9693695.

FORLINI, C. Q\&A with Dr Cynthia Forlini on the ethical issues around cognitive enhancement. HED Matters, Zürich, v. 1, n. 2, p. 6-8, 2018.

FRANKE, A. et al. Use of illicit and prescription drugs for cognitive or mood enhancement among surgeons. BMC Medicine, London, v. 11, n. 1, p. 1-9, 2013. http:// dx.doi.org/10.1186/1741-7015-11-102. PMid:23570256.

FRANKE, A. G. et al. Cannabis for cognitive enhancement as a new coping strategy? Results from a survey of students at four universities in Germany. Substance Use \& Misuse, London, v. 51, n. 14, p. 1856-1862, 2016. http://dx.doi. org/10.1080/10826084.2016.1200619. PMid:27607062.

FRASER, S.; MOORE, D. (Org.). The drug effect: health, crime and society. Port Melbourne: Cambridge University Press, 2011a. http://dx.doi.org/10.1017/ СBO9781139162142.

FRASER, S.; MOORE, D. Introduction: constructing drugs and addiction. In: FRASER, S.; MOORE, D. (Org.). The drug effect: health, crime and society. Port Melbourne: Cambridge University Press, 2011b. p. 1-18.

FRASER, S.; VALENTINE, K. Substance and substitution: methadone subjects in liberal societies. New York: Palgrave MacMillan, 2008. http://dx.doi.org/10.1057/9780230582569.

FUJIYA \& MIYAGI. Seratonin rushes. In: FUJIYA \& MIYAGI. Impossible objects of desire. United Kingdon: [s.n.], 2017.

GEREVICH, J. et al. A case report: Pavlovian conditioning as a risk factor of heroin 'overdose' death. Harm Reduction Journal, London, v. 2, n. 1, p. 11-14, 2005. http://dx.doi. org/10.1186/1477-7517-2-11.

GISH, A.; KIEPEK, N.; BEAGAN, B. Methamphetamine use among gay men: an interpretive review of a nonsanctioned occupation. Journal of Occupational Science, London, v. 1, p. 1-13, 2019. http://dx.doi.org/10.1080/ 14427591.2019.1643398.

GREEN, B.; KAVANAGH, D.; YOUNG, R. M. Reasons for cannabis use in men with and without psychosis. Drug and Alcohol Review, Abingdon, v. 23, n. 4, p. 445-453, 
2004. http://dx.doi.org/10.1080/09595230412331324 563. PMid: 15763749 .

HABIBZADEH, A. et al. Illicit methylphenidate use among Iranian medical students: prevalence and knowledge. Drug Design, Development and Therapy, Auckland, v. 5, p. 71-76, 2011. PMid:21340040.

HAPPY MONDAYS. Holiday. In: HAPPY MONDAYS. Pills 'n'thrills and bellyaches. United Kingdom: Factory, 1990.

HARRELL, P. T.; JULIANO, L. M. A direct test of the influence of nicotine response expectancies on the subjective and cognitive effects of smoking. Experimental \& Clinical Psychopharmacology, Washington, v. 20, n. 4, p. 278-286, 2012. http://dx.doi.org/10.1037/a0028652. PMid:22708609.

HELBIG, K.; MCKAY, E. An exploration of addictive behaviours from an occupational perspective. Journal of Occupational Science, London, v. 10, n. 3, p. 140-145, 2003. http://dx.doi.org/10.1080/14427591.2003.9686521.

HUGHES, P. et al. Resident physician substance use in the United States. Journal of the American Medical Association, Chicago, v. 265, n. 16, p. 2069-2073, 1991. http://dx.doi.org/10.1001/jama.1991.03460160047027. PMid:2013925.

HUTTEN, N. R. P. W. et al. A single dose of cocaine enhances prospective memory performance. Journal of Psychopharmacology, Oxford, v. 32, n. 8, p. 883-892, 2018. http://dx.doi.org/10.1177/0269881118783299. PMid:29947572.

HYSEK, C.; DOMES, G.; LIECHTI, M. MDMA enhances "mind reading" of positive emotions and impairs "mind reading" of negative emotions. Psychopharmacology, Berlin, v. 222, n. 2, p. 293-302, 2012. http://dx.doi.org/10.1007/ s00213-012-2645-9. PMid:22277989.

IP, S.; HEUBECK, B. Predictors of alcohol consumption on dates and sense of intimacy. Personal Relationships, Michigan, v. 23, n. 1, p. 124-140, 2016. http://dx.doi. org/10.1111/pere.12115.

JAGGER, M.; RICHARDS, K. Mother's little helper. In: JAGGER, M.; RICHARDS, K. Aftermath. London: Decker Records, 1966.

JANSARI, A. S. et al. Investigating the impact of nicotine on executive functions using a novel virtual reality assessment. Addiction, Abingdon, v. 108, n. 5, p. 977-984, 2013. http://dx.doi.org/10.1111/add.12082. PMid:23216905.

KEANE, H. Making smokers different with nicotine: NRT and quitting. International Journal of Drug Policy, Liverpool, v. 24, n. 3, p. 189-195, 2013. http://dx.doi. org/10.1016/j.drugpo.2013.01.011. PMid:23465645.

KIELHOFNER, G.; BURKE, J. P. A model of human occupation, part 1. Conceptual framework and content. The American Journal of Occupational Therapy, Rockville, v. 34, n. 9, p. 572-581, 1980. http://dx.doi.org/10.5014/ ajot.34.9.572. PMid:7457553.
KIEPEK, N. C. et al. Silences around occupations framed as unhealthy, illegal, and deviant. Journal of Occupational Science, London, v. 26, n. 3, p. 1-13, 2018.

KIEPEK, N. et al. Substance use by social workers and implications for professional regulation. Drugs and Alcohol Today, Brighton, v. 19, n. 2, p. 147-159, 2019. http:// dx.doi.org/10.1108/DAT-08-2018-0040.

KIEPEK, N.; MAGALHĀES, L. Addictions and impulsecontrol disorders as occupation: a selected literature review and synthesis addictions and impulse-control disorders as occupation. Journal of Occupational Science, London, v. 18, n. 3, p. 254-276, 2011. http://dx.doi.org/10.1080/1 4427591.2011 .581628 .

KIEPEK, N.; PHELAN, S.; MAGALHÁES, L. Introducing a critical analysis of the figured world of occupation. Journal of Occupational Science, London, v. 21, n. 4, p. 403-417, 2014. http://dx.doi.org/10.1080/14427591.2013.816998.

LANDE, R. G.; GRAGNANI, C. Nonpharmacologic approaches to the management of insomnia. The Journal of the American Osteopathic Association, Chattanooga, v. 110, n. 12, p. 695-701, 2010. PMid:21178150.

LE DÉVÉDEC, N. Unfit for the future? The depoliticization of human perfectibility, from the Enlightenment to transhumanism. European Journal of Social Theory, Barcelona, v. 21, n. 4, p. 488-507, 2018. http://dx.doi. org/10.1177/1368431017750974.

LEE, C. M.; NEIGHBORS, C.; WOODS, B. A. Marijuana motives: young adults' reasons for using marijuana. Addictive Behaviors, Oxford, v. 32, n. 7, p. 1384-1394, 2007. http://dx.doi.org/10.1016/j.addbeh.2006.09.010. PMid:17097817.

LEE, K. H. et al. Medical students' use of caffeine for 'academic purposes' and their knowledge of its benefits, side-effects and withdrawal symptoms. South African Family Practice, Limpopo, v. 51, n. 4, p. 322-327, 2009. http://dx.doi.org/10.1080/20786204.2009.10873872.

LORENTE, F. O.; PERETTI-WATEL, P.; GRELOT, L. Cannabis use to enhance sportive and non-sportive performances among French sport students. Addictive Behaviors, Oxford, v. 30, n. 7, p. 1382-1391, 2005. http:// dx.doi.org/10.1016/j.addbeh.2005.01.019. PMid:16022934.

LUCK, K.; BEAGAN, B. Occupational transition of smoking cessation in women: "you're restructuring your whole life. Journal of Occupational Science, London, v. 22, n. 2, p. 183-196, 2015. http://dx.doi.org/10.1080/1442 7591.2014 .887418 .

MAHER, B. Poll results: look who's doping. Nature, London, v. 452, n. 7188, p. 674-675, 2008. http://dx.doi. org/10.1038/452674a. PMid: 18401370.

MCCOMBIE, R. P.; STIRLING, J. L. Opioid substance abuse among occupational therapy clients. Occupational Therapy in Mental Health, New York, v. 34, n. 1, p. 49-60, 2018. http://dx.doi.org/10.1080/0164212X.2017.1360827. 
MCKENNA, H. et al. Qualified nurses' smoking prevalence: their reasons for smoking and desire to quit. Journal of Advanced Nursing, Oxford, v. 35, n. 5, p. 769-775, 2001. http://dx.doi.org/10.1046/j.1365-2648.2001.01909.x. PMid:11529979.

MEY, A. et al. What's the attraction? Social connectedness as a driver of recreational drug use. Journal of Substance Use, Worcester, v. 23, n. 3, p. 327-334, 2018. http://dx.doi.or $\mathrm{g} / 10.1080 / 14659891.2017 .1409816$.

MOERMAN, D. E. Explanatory mechanisms for placebo effects: cultural influences and the meaning response. In: GUESS, H. A. et al. (Org.). The science of the placebo: toward an interdisciplinary research agenda. London: BMJ Books, 2002. p. 77-107.

MOORE, D. Drugalities: the generative capabilities of criminalized 'drugs'. International Journal of Drug Policy, Amsterdam, v. 15, n. 5-6, p. 419-426, 2004. http://dx.doi. org/10.1016/j.drugpo.2004.06.008.

MOORE, T. J.; MATTISON, D. R. Adult utilization of psychiatric drugs and differences by sex, age, and race. Journal of the American Medical Association, Chicago, v. 177, n. 2, p. 274-275, 2017. http://dx.doi.org/10.1001/ jamainternmed.2016.7507. PMid:27942726.

MORISSETTE, P.; DEDOBBELEER, N. Is work a risk factor in the prescribed psychotropic drug consumption of female white-collar workers and professionals? Women o Health, Philadelphia, v. 25, n. 4, p. 105-121, 1997. http:// dx.doi.org/10.1300/J013v25n04_06. PMid:9302732.

MÓRÓ, L.; NOREIKA, V. Sacramental and spiritual use of hallucinogenic drugs. Behavioural and Brain Sciences, Cambridge, v. 34, n. 6, p. 319-320, 2011. http://dx.doi. org/10.1017/S0140525X11000768. PMid:22074972.

MÜCKE, M. et al. Pharmacological treatments for fatigue associated with palliative care. The Cochrane Database of Systematic Reviews, Oxford, v. 5, n. 5, p. CD006788, 2015. http://dx.doi.org/10.1002/14651858.CD006788.pub3. PMid:26026155.

MÜLLER, C. P.; SCHUMANN, G. Drugs as instruments: a new framework for non-addictive psychoactive drug use. The Behavioral and Brain Sciences, Irvine, v. 34, n. 6, p. 293-310, 2011. http://dx.doi.org/10.1017/ S0140525X11000057. PMid:22074962.

MUSACCHIO, N. S.; HARTRICH, M.; GAROFALO, R. Erectile dysfunction and Viagra use: what's up with college-age males? Journal of Adolescent Health, New York, v. 39, n. 3, p. 452-454, 2006. http://dx.doi.org/10.1016/j. jadohealth.2005.12.021. PMid:16919814.

NATIONAL INSTITUTE ON DRUG ABUSE - NIH. Hallucinogens and dissociative drugs. Maryland, 2015. (Research Report Series). Available from: <https://d14rmgtrwzf5a. cloudfront.net/sites/default/files/hallucinogensrrs4.pdf $>$. Access on: 1 Sept. 2019.

NEWBURY-BIRCH, D.; WALSHAW, D.; KAMALI, F. Drink and drugs: from medical students to doctors. Drug and Alcohol Dependence, Lausanne, v. 64, n. 3, p. 265-270,
2001. http://dx.doi.org/10.1016/S0376-8716(01)001284. PMid:11672941.

NEWBURY-BIRCH, D.; WHITE, M.; KAMALI, F. Factors influencing alcohol and illicit drug use amongst medical students. Drug and Alcohol Dependence, Lausanne, v. 59, n. 2, p. 125-130, 2000. http://dx.doi.org/10.1016/ S0376-8716(99)00108-8. PMid:10891625.

NEWHOUSE, P. et al. Nicotine treatment of mild cognitive impairment: a 6-month double-blind pilot clinical trial. Neurology, Minneapolis, v. 78, n. 2, p. 91-101, 2012. http://dx.doi.org/10.1212/WNL.0b013e31823efcbb. PMid:22232050.

NHUNZVI, C.; GALVAAN, R.; PETERS, L. Recovery from substance abuse among Zimbabwean men: an occupational transition. OTJR: Occupation, Participation and Health, Thorofare, v. 39, n. 1, p. 14-22, 2019. http:// dx.doi.org/10.1177/1539449217718503. PMid:28685660.

NOUR, M. M.; CARHART-HARRIS, R. L. Psychedelics and the science of self-experience. The British Journal of Psychiatry, London, v. 210, n. 3, p. 177-179, 2017. http:// dx.doi.org/10.1192/bjp.bp.116.194738. PMid:28249943.

OSBOURNE, O. et al. Sweet leaf. In: OSBOURNE, O. Master of reality. Califórnia: Warner Bros. Records, 1971.

PARTRIDGE, B. A re-think on drug policy in sport requires an enhanced conception of enhancement. Performance Enhancement \& Health, Australia, v. 2, n. 2, p. 76-77, 2013. http://dx.doi.org/10.1016/j.peh.2013.08.012.

PETROIANU, A. et al. Prevalence of alcohol, tobacco and psychotropic drug consumption by medical students of the "Universidade Federal de Minas Gerais". Revista da Associação Médica Brasileira, São Paulo, v. 56, n. 5, p. 568-571, 2010. http://dx.doi.org/10.1590/S010442302010000500019. PMid:21152830.

PIASECKI, T. M. et al. The subjective effects of alcoholtobacco co-use: an ecological momentary assessment investigation. Journal of Abnormal Psychology, Washington, v. 120, n. 3, p. 557-571, 2011. http://dx.doi.org/10.1037/ a0023033. PMid:21443289.

POULSEN, M. Embodied subjectivities: bodily subjectivity and changing boundaries in post-human alcohol practices. Contemporary Drug Problems, Australia, v. 42, n. 1, p. 3-19, 2015. http://dx.doi.org/10.1177/0091450915569499.

RACE, K. Pleasure consuming medicine: the queer politics of drugs. Durham: Duke University Press, 2009. http:// dx.doi.org/10.1215/9780822390886.

RACINE, E.; FORLINI, C. Cognitive enhancement, lifestyle choice or misuse of prescription drugs?: ethics blind spots in current debates. Neuroethics, Oxford, v. 3, n. 1, p. 1-4, 2010. http://dx.doi.org/10.1007/s12152008-9023-7.

REINER, M.; GRUZELIER, J.; BAMIDIS, P. D. Cognitive enhancement: a system view. International Journal of Psychophysiology, Amsterdam, v. 122, p. 1-5, 
2017. http://dx.doi.org/10.1016/j.ijpsycho.2017.07.011. PMid:28754327.

REPANTIS, D. et al. Modafinil and methylphenidate for neuroenhancement in healthy individuals: a systematic review. Pharmacological Research, London, v. 62, n. 3, p. 187206, 2010. http://dx.doi.org/10.1016/j.phrs.2010.04.002. PMid:20416377.

RICH, A. et al. Event-level analysis of anal sex roles and sex drug use among gay and bisexual men in Vancouver, British Columbia, Canada. Archives of Sexual Behavior, New York, v. 45, n. 6, p. 1443-1451, 2016. http://dx.doi. org/10.1007/s10508-015-0607-0. PMid:26525571.

ROJO-MOTA, G.; PEDRERO-PÉREZ, E. J.; HUERTASHOYAS, E. Systematic review of occupational therapy in the treatment of addiction: Models, practice, and qualitative and quantitative research. The American Journal of Occupational Therapy, Rockville, v. 71, n. 5, p. 1-11, 2017. http://dx.doi.org/10.5014/ajot.2017.022061. PMid:28809648.

SCHMID, Y.; LIECHTI, M. Long-lasting subjective effects of LSD in normal subjects. Psychopharmacology, Berlin, v. 235, n. 2, p. 535-545, 2018. http://dx.doi.org/10.1007/ s00213-017-4733-3. PMid:28918441.

SCHWARTZ, J. R. L.; ROTH, T. Shift work sleep disorder: burden of illness and approaches to management. Drugs, New York, v. 66, n. 18, p. 2357-2370, 2006. http://dx.doi.org/10.2165/00003495-200666180-00007. PMid:17181377.

SMITH, J. Monitoring nurses with substance-use disorders in New Jersey. Nursing Clinics of North America, Philadelphia, v. 48, n. 3, p. 465-468, 2013. http://dx.doi.org/10.1016/j. cnur.2013.05.003. PMid:23998772.

SOLOWIJ, N.; HALL, W.; LEE, N. Recreational MDMA use in Sydney: a profile of 'Ecstasy' users and their experiences with the drug. British Journal of Addiction, Oxfordshire, v. 87, n. 8, p. 1161-1172, 1992. http://dx.doi. org/10.1111/j.1360-0443.1992.tb02003.x. PMid:1354992.

SPROULE, B. et al. The use of non-prescription sleep products in the elderly. International Journal of Geriatric Psychiatry, Chichester, v. 14, n. 10, p. 851-857, 1999. http://dx.doi. org/10.1002/(SICI)1099-1166(199910)14:10<851::AIDGPS33>3.0.CO;2-L. PMid:10521884.

STADHEIM, $\mathrm{H}$. et al. Caffeine increases performance in cross-country double-poling time trial exercise. Medicine \& Science in Sports \& Exercise, Madison, v. 45, n. 11, p. 2175-2183, 2013. http://dx.doi.org/10.1249/ MSS.0b013e3182967948. PMid:23591294.

SY, M. P. et al. Articulating the form, function, and meaning of drug using in the Philippines from the lens of morality and work ethics. Journal of Occupational Science, London, p. 1-10, 2019. In press. http://dx.doi.org/10.10 80/14427591.2019.1644662.

TEMPLE, J. L. et al. Systematic review and metaanalysis of the effects of caffeine in fatigued shift workers: implications for emergency medical services personnel.
Prehospital Emergency Care, Philadelphia, v. 22, p. 37-46, 2018. Suplement 1. http://dx.doi.org/10.1080/1090312 7.2017.1382624. PMid:29324066.

TER BOGT, T. et al. "Dancestasy": dance and MDMA use in Dutch youth culture. Contemporary Drug Problems, Australia, v. 29, n. 1, p. 157-181, 2002. http://dx.doi. org/10.1177/009145090202900107.

THAL, S. B.; LOMMEN, M. J. J. Current perspective on MDMA-assisted psychotherapy for posttraumatic stress disorder. Journal of Contemporary Psychotherapy, New York, v. 48, n. 2, p. 99-108, 2018. http://dx.doi.org/10.1007/ s10879-017-9379-2. PMid:29720767.

TOWNSEND, E. A.; POLATAJKO, H. J. Enabling occupation II: advancing an occupational therapy vision for health, well-being, \& justice through occupations. Ottawa: CAOT Publications ACE, 2007.

TRIVIÑO, J. L. P. Mood enhancement and doping. Performance Enhancement \& Health, Australia, v. 3, n. 1, p. 26-30, 2014. http://dx.doi.org/10.1016/j.peh.2014.06.003.

TUPPER, K. W. Entheogens and existential intelligence: the use of plant teachers as cognitive tools. Canadian Journal of Education, Ottawa, v. 27, n. 4, p. 499-516, 2002. http://dx.doi.org/10.2307/1602247.

VRECKO, S. Just how cognitive is "cognitive enhancement"? On the significance of emotions in university students' experiences with study drugs. AJOB Neuroscience, Philadelphia, v. 4, n. 1, p. 4-12, 2013. http://dx.doi.or g/10.1080/21507740.2012.740141. PMid:23486311.

WARDLE, M. C.; DE WIT, H. MDMA alters emotional processing and facilitates positive social interaction. Psychopharmacology, Berlin, v. 231, n. 21, p. 4219-4229, 2014. http://dx.doi.org/10.1007/s00213-014-3570-x. PMid:24728603.

WASMUTH, S.; BRANDON-FRIEDMAN, R. A.; OLESEK, K. A grounded theory of veterans' experiences of addiction-as-occupation. Journal of Occupational Science, London, v. 23, n. 1, p. 128-141, 2016. http://dx.doi.org /10.1080/14427591.2015.1070782.

WASMUTH, S.; CRABTREE, J. L.; SCOTT, P. J. Exploring addiction-as-occupation. The British Journal of Occupational Therapy, London, v. 77, n. 12, p. 605-613, 2014. http:// dx.doi.org/10.4276/030802214X14176260335264.

WEBB, J. R.; VALASEK, M. A.; NORTH, C. S. Prevalence of stimulant use in a sample of US medical students. Annals of Clinical Psychiatry, New York, v. 25, n. 1, p. 27-32, 2013. PMid:23376866.

WHITE, B. P.; BECKER-BLEASE, K. A.; GRACEBISHOP, K. Stimulant medication use, misuse, and abuse in an undergraduate and graduate student sample. Journal of American College Health, Washington, v. 54, n. 5, p. 261-268, 2006. http://dx.doi.org/10.3200/ JACH.54.5.261-268. PMid:16539218.

WHITTEMORE, R.; KNAFL, K. The integrative review: updated methodology. Journal of Advanced Nursing, 
Oxford, v. 52, n. 5, p. 546-553, 2005. http://dx.doi. org/10.1111/j.1365-2648.2005.03621.x. PMid:16268861.

YANG, M. S.; YANG, M. J.; PAN, S. M. Prevalence and correlates of substance use among clinical nurses in Kaohsiung City. Kaohsiung Journal of Medical Sciences, Taiwan, v. 17, n. 5, p. 261-269, 2001. PMid:11517865.

YOUNG, S.; MOSKOWITZ, D.; AAN HET ROT, M. Possible role of more positive social behaviour in the clinical effect of antidepressant drugs. Journal of Psychiatry
\& Neuroscience, Ottawa, v. 39, n. 1, p. 60-65, 2014 http://dx.doi.org/10.1503/jpn.130165. PMid:24280182.

ZDUN, S. The perceived effects of cocaine on the driving performance of long-term users. Drugs: Education, Prevention and Policy, Denmark, v. 21, n. 5, p. 420 425, 2014.

ZOHNY, H. The myth of cognitive enhancement drugs. Neuroethics, Oxford, v. 8, n. 3, p. 257-269, 2015. http:// dx.doi.org/10.1007/s12152-015-9232-9.

\section{Author's Contributions}

Niki Kiepek, Brenda Beagan and Shanon Phelan contributed to the writing and revision of the text. All authors approved the final version of the text. 